\title{
SOSIALISASI MEDIA PITA BILANGAN MATEMATIKA SISWA SEKOLAH DASAR DESA GELANGSAR LOMBOK BARAT
}

\author{
Mahsup ${ }^{1}$, Yunita Septiana Anwar ${ }^{2}$ \\ 1, 2 Pendidikan Matematika, FKIP Universitas Muhammadiyah Mataram \\ supyeka@gmail.com, na2_math@yahoo.com
}

\begin{abstract}
ABSTRAK
Abstrak: Tujuan kegiatan pengabdian untuk mengetahui proses sosialisasi dengan menggunakan media Pita bilangan dan Bimbingan Belajar Matematika untuk menigkatkan pemahaman dalam berhitung matematika siswa SD di Desa Gelangsar. Metode Pengabdian yang digunakan adalah metode deskriptif. Rancangan Pengabdian terdiri dari tahap perencanaan dan pelaksanaan tindakan. Sasaran kegiatan adalah anak SD dengan jumlah anak sekitar 20 orang yang berada di Gelangsar Kecamatan Gunungsari Kabupaten Lombok Barat. Kegiatan dilaksanakan selama 1 hari dilakukan di desa Gelangsar Kecamatan Gunungsari Kabupaten Lombok Barat. Hasil kegiatan pengabdian yaitu (1) kegiatan sosialisasi penggunaan media pita sangat bermanfaat untuk meningkatkan pemahaman siswa terhadap materi bilangan bulat, (2) Kegiatan sosialisasi dapat mendorong siswa supaya lebih giat belajar dan berlatih dalam mengerjakan perhitungan operasi bilangan bulat dan (3) dengan kegiatan pelatihan dapat menambah informasi dalam penggunaan media khususnya pita bilangan.
\end{abstract}

Kata Kunci: Alat Peraga, Pembelajaran Matematika

\begin{abstract}
The purpose of this study was to find out how introducing Pita number media dan an intensive math tutoring could improve the understanding of the elementary students of Gelangsar village in counting numbers. The research method used was descriptive qualitative. The research plan consisted of planning and action. There were 20 elementary students of Gelangsar village in Gunung Sari district of west Lombok. The implementation was conducted in one day treatment in Gelangsar village in Gunung Sari district of west Lombok. The result of the study indicated that (1) introducing the students using Pita number media could improve their understanding in counting integers, (2) this introduction could stimulate the students to be more motivated in learning counting integers and (3) this introduction also could be a reference on the use of Pita number media.
\end{abstract}

Keywords: Visual aid equipment, Learning Mathematics

Riwayat Artikel: Diterima: 7-12-2017, Disetujui: 13-12-2017 


\section{A. LATAR BELAKANG}

Desa Gelangsar dengan Kecamatan Gunungsari Kabupaten Lombok Barat merupakan wilayah yang sangat strategis sebagai tempat pengembangan pembangunan pada masa yang akan datang. Pengembangan tersebut meliputi bidang ekonomi, industry dan pertanian. Berdasarkan geografisnya, wilayah desa Gelangsar sebagian besar merupakan dataran rendah yang sangat luas dan subur dengan dikelilingi oleh pegunungan.

Berdasarkan keadaan alamnya yang sangat subur, bidang pertanian merupakan sumber pencaharian terbesar khususnyan tanaman padi dan sayur-sayuran. Hal ini terjadi karena sebanyak $90 \%$ wilayah merupakan daerah persawahan yang sangat cocok ditanami oleh tanaman seperti padi, jagung, sayur maupun tanaman holtikultura lainnya. Dengan adanya keadaan seperti ini, desa Gelangsar merupakan salah satu desa penghasil padi terbesar selain desa lain yang ada diwilayah Lombok.

Dalam bidang pendidikan anak siswa Sekolah Dasar (SD) di desa Gelangsar masih tergolong rendah karena perhatian para orang tua terhadap pendidikan anak-anaknya masih kurang. Hal ini disebabkan karena dari latar belakang pendidikan para orang tua yang rata-rata tamatan SMA dan pekejaan para orang tua yang mayoritas sebagai petani sehingga perhatian terhadap anak pada siswa SD masih rendah. Dengan melihat penomena tersebut sangat berpengaruh terhadap pendidikan anak.

Kemampuan siswa SD di desa Gelangsar dalam berhitung masih tergolong sangat rendah terutama dalam melakukan operasi penjumlahan, perkalian, pembagian dan pengurangan karena dalam perhitungan matematika tersebut bersifat abstrak. Untuk memudahkan anak dalam berhitung atau malakukan operasi berhitung matematika bisa disajikan dalam bentuk yang konkrit maka perlu ada media yang membantu dalam proses tersebut. Salah satu media dalam matematika yang digunakan adalah media Pita Bilangan.

Pita Bilangan adalah digunakan untuk menjelaskan serta memperagakan konsep perhitungan operasi penjumlahan dan pengurangan perkalian dan pembagian pada bilangan Asli. Dalam pembelajaran Matematika Pita bilangan memiliki beberapa fungsi antara lain: (1) memperagakan perhitungan operasi penjumlahan, (2) memperagakan perhitungan operasi pengurangan, (3) memperagakan perhitungan operasi perkalian, dan (4) memperagakan perhitungan operasi pembagian pada bilangan asli.

1. Permasalahan

Dari analisis situasi yang telah uraikan di atas maka permasalahanya adalah bagaimana proses sosialisasi menggunakan media Pita bilangan dan Bimbingan Belajar Matematika untuk menigkatkan pemahaman dalam berhitung matematika siswa SD di Desa Gelangsar?

2. Tujuan

Untuk mengetahui proses sosialisasi dengan menggunakan media Pita bilangan dan Bimbingan Belajar Matematika untuk menigkatkan pemahaman dalam berhitung matematika siswa SD di Desa Gelangsar. 
Mahsup, Sosialisasi Media Pita ...

3. Solusi yang Ditawarkan

Solusi yang ditawarkan setelah mengikuti kegiatan Pelatihan penggunaan media pita bilangan sebagai berikut:

a. Penggunaan media pita bilangan dapat memudahkan siswa dalam melakukan proses hitung matematika (Penjumlahan, pengurangan, perkalian dan pembagian)

b. Dapat melatih kecepatan anak SD dalam melakukan perhitungan matematika

4. Manfaat Kegiatan Pengabdian

Dari kegiatan pengabdian masyarakat diharapakan dapat memberikan manfaat sebagai berikut:

a. Manfaat Teoritis

Anak SD dapat menggunakan media pita bilangan untuk melakukan perhitung matematika

b. Manfaat Praktis

Anak SD dapat menjadikan media pita bilangan sebagai alat yang dapat membantu dalam melakukan proses berhitung matematika

\section{B. MEDIA PEMBELAJARAN}

Media adalah sebuah alat yang mempunyai fungsi menyampaikan pesan (Bovee, 1997). Media pembelajaran adalahsebuah alat yang berfungsi dan digunakan untuk menyampaikan pesan pembelajaran. Pembelajaran adalah proses komunikasi antara siswa, pengajar, dan bahan ajar. Banyak batasan atau pengertian yang dikemukakan para ahli tentang media, diantaranya adalah: Asosiasi Teknologi dan Komunikasi Pendidikan (Asosociation of Education and Communication Technology (AECT). Dari pengertian diatas, secara umum dapat dikatakan bahwa substansi dari media pembelajaran adalah bentuk saluran, yang digunakan untuk menyalurkan pesan, informasi atau bahan pelajaran kepada penerima pesan atau siswa dapat pula dikatakan bahwa media pembelajaran adalah berbagai jenis komponen dalam lingkungan dalam lingkungan siswa yang dapat merangsang siswa untuk belajar.

Tujuan media pembelajaran sebagai alat bantu pembelajaran, adalah sebagai berikut; (1) mempermudah proses pembelajaran di kelas; (2) meningkatkan efisiensi proses pembelajaran; (3) menjaga relevansi antara materi pelajaran dengan tujuan belajar; (4) membantu konsentrasi siswa dalam proses pembelajaran. Manfaat media pembelajaran sebagai alat bantu dalam proses pembelajaran adalah sebagai berikut : (1)pengajaran lebih menarik perhatian siswa sehingga dapat menumbuhkan motivasi belajar; (2) bahan pengajaran akan lebih jelas maknanya, sehingga dapat lebih di pahami siswa, serta memungkinkan siswa menguasai tujuan pengajaran dengan baik; (3) metode pembelajaran bervariasi, tidak sematasemata hanya komunikasi verbal melalui penuturan katakata lisan pengajar, siswa tidak bosan, dan pengajar tidak kehabisan tenaga; (4) siswa lebih banyak melakukan kegiatan belajar, sebab tidak hanya mendengarkan penjelasa dari pengajar saja, tetapi juga aktivitas lain yang dilakukan seperti mengamati, melakukan, mendemonstrasikan dan lainlainya. 
Manfaat Media pembelajaran bagi pengajar, yaitu: (1) memberikan pedoman, arah untuk mencapai tujuan; (2) menjelaskan struktur dan urutan pengajarn dengan baik; (3) memberikan kerangka sistematis secara baik; (4) memudahkan kembali pengajar terhadap materi pembelajaran; (5) membantu kecermatan, ketelitian dalam penyajian dalam pembelajaran; (6) rasa percaya diri seorang pengajar; (7) meningkatkan kualitas pembelajaran;

Manfaat media pembelajaran bagi siswa, yaitu: (1) meningkatkan motivasi belajar siswa; (2) memberikan dan meningkatkan variasi belajar siswa; (3) memberikan struktur materi pelajaran; (4) memberikan inti informasi pelajaran; (5) merangsang siswa untuk berpikir dan beranalisis.; (6) menciptakan kondisi dan situasi belajar tanpa tekanan; (7) pelajar dapat memahami materi pelajaran dengan sistematis yang disajikan pengajar; Perpita media yang akan digunakan dalam pembelajaran menjadi perpita utama, karena media yang dipilih harus sesuai dengan: (1) tujuan pengajaran; (2) bahan pelajaran; (3) metode mengajar; (4) alat yang dibutuhkan; (5) minat dan kemampuan mengajar; (6) situasi pengajaran yang sedang berlangsung Media Pembelajaran berfungsi untuk merangsang pembelajaran dengan: (1) menghadirkan obyek sebenarnya; (2) membuat duplikasi dari obyek yang sebenarnya; (3) konsep abstrak ke konsep konkret; (4) memberi kesamaan persepsi; (5) mengatasi hambatan waktu, tempat, jumlah, dan jarak; (6) menyajikan ulang informasi secara konsisten; (7) memberi suasana yang belajar yang tidak tertekan, santai, dan menarik.

Menurut Gie (2010), aktivitas belajar adalah segenap rangkaian kegiatan atau aktivitas secara sadar yang dilakukan oleh seseorang yang mengakibatkan perubahan dalam dirinya, berupa perubahan pengetahuan atau kemahirannyang sifatnya tergantung pada sedikit banyaknya perubahan.

Sedangkan menurut Sardiman (2010), aktivitas dalam proses belajar mengajar adalah rangkaian kegiatan yang meliputi keaktifan siswa dalam mengikuti pelajaran, bertanya hal yang belum jelas, mencatat, mendengar, berpikir, membaca dan segala kegiatan yang dilakukan yang dapat menunjang prestasi belajar. Hasil belajar merupakan hasil nilai yang diperoleh siswa dari hasil evaluasi setelah kegiatan proses pembelajaran. Menurut Winkel (1991) meyataka bahwa hasil belajar adalah bukti keberhasilan dan usaha yang dilakuakan dan merupakan kecakapan yang diperoleh melalui kegiatan pembelajaran di sekolah yang dinyatakan dengan angka.

Selanjutnya Soemantri (2001) mengatakan bahwa hasil belajar merupakan suatu indikator dari perubahan yang terjadi pada diri siswa setelah mengalami proses belajar dimana untuk mengungkapnya biasanya menggunakan suatu alat penilaian yang ditetapkan sekolah oleh guru. Dalam dunia pendidikan khususnya sekolah hasil belajar merupakan nilai yang diperoleh siswa terhadap suatu mata pelajaran tertentu.

Suryabrata (1988) mengemuka-kan bahwa ada dua factor yang mempengaruhi hasil belajar seseorang, yaitu: (1) faktor yang berasal dari luar diri si pelajar, yaitu faktor social dan faktor non sosial, (2) faktor yang berasal dari dalam diri pelajar, yaitu faktor psikologis dan fisiologis. Hal ini sejalan dengan pendapat hasil belajar yang dicapai siswa dipengaruhi oleh dua faktor utama yaitu: faktor dari dalam siswa dan faktor yang datang 
dari luar diri siswa atau lingkungan. Faktor dari dalam diri siswa terutama menyangkut kemampuan yang dimiliki siswa. Berkaitan dengan faktor dari dalam diri siswa, selain faktor kemampuan, ada juga faktor lain yaitu motivasi belajar, minat, perhatian, sikap, kebiasaan belajar, ketekunan, kondisi ekonomi, kondisi fisik dan psikis. Sedangkan faktor dari luar atau lingkungan yang paling dominan mempengaruhi hasil belajar adalah kualitas pembelajaran.

\section{PROFIL DESA GELANGSAR}

\section{Letak Geografi, Topografi, Dan Demograsi Desa}

Desa Gelangsar merupakan salah satu desa dari 16 desa yang terdapat di wilayah Lombok Barat dan merupakan salah satu desa dari 16 desa yang terdapat pada wilayah kerja kec. Gunungsari. Adapun batas wilayah desa tersebut adalah sebagai berikut:

- Sebelah Barat: Desa Dopang

- Sebelah Timur: Desa Mekarsari

- Sebelah Selatan : Desa Jeringo

- Sebelah Utara : Hutan Lindung/ KLU

Wilayah pemerintah Desa Gelangsar kec. Gunungsari, kabupaten Lombok Barat terbagi atas 6 (enam) dusun yaitu Dusun Gelangsar, dusun Gelangsar Timur, dusun Lilir Utara, dusun Songoran, dusun Apit Aiq, dan dusun Gripak . Dari enam dusun tersebut terbagi menjadi 14 rukun tetangga (RT), dan 8 Rukun warga (RW). Dari semua jumlah RT yang ada terdapat 1001 KK (Kepala Keluarga)

\section{Luas wilayah}

Desa Gelangsar merupakan daerah dataran tinggi dimana penggunaan tanahnya sebagian tidak sama dengan desa-desa lainnya, ini tergantung dari wilayah, kondisi, situasi desa yang bersangkutan.

\section{Keadaan iklim}

Desa Gelangsar tergolong daerah atau wilayah beriklim tropis dengan transformatur minimum rata-rata $23^{\circ} \mathrm{C}$ dan maksimum $30{ }^{\circ} \mathrm{C}$. Pada umumnya hujan turun pada bulan Oktober-November. Sedangkan musim kemarau berlangsung pada bualan April-September. Dari keadaan iklim tersebut para petani dapat memanfaatkan keadaan yang menguntungkan ini, untuk menanami sawahnya dengan penanaman tanaman padi satu kali, ditambahkan dengan tanamanan kacang, dan kedelai untuk setiap tahun nya.

\section{Sosial, Budaya dan Pendidikan}

a. Adat istiadat yang masih di laksakan didesa Gelangsar Jenis adat yang masih dilaksakan diwilayah Desa Gelangsar sebagai berikut:

1) Musyawarah adat

2) Perkawinan adat

3) Upacara pernikahan secara adat

4) Memperingati hari-hari besar keagamaan.

b. Kesenian

Kesenian yang menjadi kesukaan masyarakat Desa Gelangsar antara lain: kecimol dan celokak.

c. Pendidikan

Dalam meningkatkan sumber Daya Manusia (SDM) maka pemerintah Desa bekerja sama dengan industri terkait (Dinas 
pendidikan) telah membuka sarana dan prasarana dalam mengunjang kegiatan belajar mengajar seperti:

$\begin{array}{lll}\text { TK } & 2 & \text { unit } \\ \text { Jumlah murid } & 27 & \text { orang } \\ \text { Jumlah guru } & 5 & \text { orang } \\ \text { SD/derajat } & 2 & \text { unit } \\ \text { Jumlah murid } & 300 & \text { orang } \\ \text { Jumlah guru } & 26 & \text { orang }\end{array}$

\section{Keluarga Berencana dan Keluarga Prasejahtera}

Sebagian besar masyarakat desa Gelangsar berpendapat bahwa, program keluarga berencana(KB) yang dicangkangkan oleh pemerintah merupakan alternatif yang tepat, guna menurunkan angka kematian pada ibu dan bayi. Disamping itu, dengan progran keluarga berencana (KB) ini maka pemerintah dapat menurunkan angka kepadatan penduduk disetiap tahunnya. Jumlah orang yang KB pada tahun 2017 sebanyak 157 orang.

\section{Sarana Dan Prasarana Transportasi}

a. Jalan

Untuk memudahkan askes masyarat sekitar, pemerintah telah mengupayakan pembangunan jalan aspal sepanjang jalan penghubung antara desa-desa sekecamatan Gunungsari, dan jalan penghubung antara dusun-dusun se desa Gelangsar masih dalam proses perbaikan dan pembenahan sesuai dengan program jangka panjang. Panjang jalang aspal $400 \mathrm{~m}$ dan hotmik $250 \mathrm{~m}$ serta rusak $350 \mathrm{~m}$.

b. Jembatan

Untuk menghubungkan antara satu dusun ke dusun lain, atau dari Desa Gelangsar kedesa yang lain tentu dibutuhkan jembatan sebagai sarana untuk memudahkan alat tranportasi untuk mencapai tujuan. Dan di desa Gelangsar terdapat 2 unit jembatan yang terdapat dari besi beton.

c. Alat- alat transportasi

Alat transfortasi yang digunakan oleh sebagian besar masyarakat Desa Gelangsar adalah kendaraan roda empat seperti: sepeda motor, bemo, engkel, dan truk. Jumlah kedaraan roda empat sebanyak 3 unit.

\section{METODE PELAKSANAAN}

\section{Metode Pengabdian}

Metode yang digunakan dalam ini adalah metode deskriptif. Metode deskriptif adalah suatu metode dalam penelitian status kelompok manusia, suatu objek, suatu set kondisi, suatu sistem pemikiran, ataupun suatu peristiwa pada masa sekarang.

\section{Rancangan Pengabdian}

Langkah-langkah pengabdian terdiri dari tahap perencanaan dan pelaksanaan tindakan. 


\section{Sasaran Kegiatan}

Sasaran kegiatan adalah anak SD dengan jumlah anak sekitar 20 orang yang berada di Gelangsar Kecamatan Gunungsari Kabupaten Lombok Barat.

\section{Waktu dan Tempat}

Kegiatan dilaksanakan selama 1 hari yang dirangkaikan dengan realisasi Program Mahasiswa KKN.Kegiatan dilakukan di desa Gelangsar Kecamatan Gunungsari Kabupaten Lombok Barat

\section{E. HASIL DAN PEMBAHASAN}

\section{Pelaksanaan Kegiatan}

Kegitan pelatihan dilaksanakan selama 1 hari. Sebelum ke lokasi pengabdian terlebih dahulu tim membuat media pita bilangan. Kegiatan pelatihan media pita bilangan dilaksanakan pada tanggal 3 November 2017 mulai pukul 14.00 sampai dengan pukul 15.30 Wita. Kegiatan pelatihan dihadiri oleh 15 siswa SD mulai kelas IV sampai dengan kelas VI.

Kegiatan diawali dengan menjelaskan terlebih dahulu cara konsep pita bilangan dimana ada beberapa prinsip yang harus diperhatikan dalam penggunaan media pita garis bilangan untuk peragaan hitung pada bilangan bulat, yaitu (1) setiap akan melakukan peragaan, posisi awal peragaan harus dimulai dari bilangan 0 nol. (2) untuk bilangan bulat positif dengan cara menghadap ke bilangan positif kanan dan maju bila menunjukkan simbol penjumlahan, begitu pula sebaliknya mundur bila menunjukkan simbol pengurangan. Untuk bilangan negatif dengan cara menghadap ke bilangan negatif kiri dan mundur bila simbol menunjukkan pengurangan begitu pula sebaliknya maju bila menunjukkan simbol penjumlahan pada garis bilangan yang digunakan. Misalnya untuk menunjukkan angka 5, caranya adalah pertama, berdiri di angka nol, kemudian menghadap ke kanan maju dan berhenti di angka 5 .

Sedangkan untuk menunjukkan angka bilangan -5 , caranya yang pertama adalah berdiri di angka nol, kemudian menghadap ke kiri, maju hingga berhenti di angka -5. (3) untuk operasi hitung pengurangan bilangan bulat, berdiri menghadap ke angka yang akan dikurangi kemudian maju sejauh angka yang akan dikurangi kemudian menghadap kekiri maju atau mundur sejauh angka pengurangnya. Posisi angka nol hingga tempat akhir berdiri merupakan hasil akhir dari pengurangan kedua bilangan bulat tersebut. Seperti contoh: Nyatakan hasil dari -7- (-19). Langkah kerja pada media pita garis bilangan dalam pengurangan bilangan bulat adalah sebagai berikut: (a) Pertama berdiri di angka nol, (b) Kemudian menghadap ke kiri sebanyak 7 garis kotak hingga berdiri di angka -7, (c) Karena dikurangi, maka menghadap kekiri. Langkah selanjutnya setelah menghadap kekiri, karena negatif -19 maka mundur sebanyak 19 kotak garis. (d) Tempat berdiri akhir merupakan hasil akhir dari pengurangan bilangan bulat. dari angka nol hingga tempat akhir berdiri 


\section{Kontribusi Mitra}

Kegiatan pelatihan pita bilangan memberikan kontribusi bagi siswa yaitu:

a. Siswa memahami proses perhitungan operasi penjumlahan, pengurangan, perkalian dan pembagian pada bilangan bulat

b. Dapat memudahkan siswa dalam melakukan proses perhitungan operasi bilangan bulat

c. Siswa dalam berhitungan matematika lebih menyenangkan dan tidak membosankan

d. Dapat meningkatkan pemahaman siswa dalam melakukan perhitungan operasi bilangan bulat

\section{Potret Permasalahan Mitra}

Masalah yang dihadapi siswa SD di desa Gelangsar adalah (1) kurangnya media pembelajaran matematika, (2) siswa tidak dapat menggunakan media pembelajaran karena kurangnya pemahaman yang diberikan oleh guru, (3) terbatasnya dana dalam pembelian media oleh sekolah SD, (4) kurangnya kreativitas guru dalam pembuatan media pembelajaran khususnya media pembelajaran matematika, (5) kurangnya kegiatan worshop dan pelatihan pembuatan media yang diikuti oleh guru baik di tingkat lokal dan nasional, (6) Musyawarah Guru Mata Pelajarn (MGMP) khususnya mata pelajaran matematika tidak berjalan.

\section{F. SIMPULAN DAN SARAN}

\section{Kesimpulan}

Dari kegiatan pengabdian kepada masyarakat berupa kegiatan pelatihan media pita desa Gelangsar disimpulkan sebagai berikut:

a. Kegiatan sosialisasi penggunaan media pita sangat bermanfaat untuk meningkatkan pemahaman siswa terhadap materi bilangan bulat.

b. Kegiatan pelatihan dapat mendorong siswa supaya lebih giat belajar dan berlatih dalam mengerjakan perhitungan operasi bilangan bulat.

c. Dengan kegiatan pelatihan dapat menambah informasi dalam

2. Saran penggunaan media khususnya pita bilangan

Dalam proses pembelajaran media pembelajaran sangat dibutuhkan untuk memudahkan siswa dalam memahami konsep matematika khususnya bilangan bulat, maka diharapkan ketersediaan media pembelajaran disekolah harus ada, karena dengan penggunaan media pembelajaran dalam psoses pembelajaran diharapkan dapat meningkatkan pemahaman dan hasil belajar matematika.

\section{UCAPAN TERIMA KASIH}

Tim pengabdian kepada masyarakat mengucapkan terima kasih kepada Lembaga Pengabdian Pada Masyarakat (LPPM) Universitas Muhammadiyah Mataram yang telah mendanai kegiatan pengabdian ini sehingga terlaksana dengan baik. 


\section{DAFTAR PUSTAKA}

[1] Depdiknas, Pembelajaran Matematika Di Sekolah Dasar, (http://www.sekolahdasar.net/2017/12/, diakses pada tanggal 5 Desember 2017.

[2] DP2M Dikti. Panduan Pengabdian Kepada Masyarakat, Buku VII. Jakarta. 2017

[3] LPM. Panduan Program Pengabdian Kepada Masyarakat UMM. 2017. Mataram

[4] Profil Desa Gelangsar Kecamatan Gunungsari Lombok Barat. 